\title{
SPORT TEXTS IN TEACHING POLISH AS A FOREIGN LANGUAGE
}

(THIS ARTICLE WAS TRANSLATED FROM POLISH BY JAKUB WOSIK)

\begin{abstract}
Keywords: text, media text, media sport texts, popular culture in teaching Polish as a foreign language

Abstract. In this article I present the potential of media sport texts in terms of their utilisation in Polish as a foreign language classes. I discuss various definitions of text to indicate that it can constitute not only a linguistic concept but can also carry a communal element, a state of one's spirit if you will. Next, I indicate the role of media texts in foreign language teaching. Further, I discuss the role of culture, popular culture in particular, in foreign language teaching. I also reference studies which have indicated the differences in how the same media genres are constructed in various linguistic contexts. My original proposal applies to sport texts, be they broadcast on the radio, television, or the internet. I indicate their potential in foreign language teaching and specific areas in which they may be applied. I conclude by discussing the advantages and disadvantages of utilising sport-themed media texts in Polish as a foreign language classes.
\end{abstract}

Texts are part of the teaching process at every step. Academic studies into foreign language teaching include both theoretical studies regarding the text as a concept, and practical studies that discuss the utilisation of various text types in foreign language teaching, including teaching Polish as a foreign language (PFL) ${ }^{1}$. The focus of studies related to the theory of text falls mainly on the issues related to defining the limits of text, a problem which could be reduced to the question of what a text is and what it is not. According to the so-called textological definition

*beata.grochala@uni.lodz.pl, Uniwersytet Łódzki, Wydział Filologiczny, Instytut Filologii Polskiej i Logopedii, Zakład Lingwistyki Stosowanej i Kulturowej, ul. Pomorska 171/173, 90-236 Łódź.

${ }^{1}$ Texts in teaching PFL have been discussed extensively in, e.g., the articles published in three issues of the "Acta Universitatis Lodziensis. Kształcenie Polonistyczne Cudzoziemców” journal (vol. 16/2008, vol. 17/2010, and vol. 18/2011). 
of text, based on the works of, e.g., Renata Mayenowa and Teresa Dobrzyńska ${ }^{2}$, "text is a supra-sentence (i.e., typologically higher, not necessarily in terms of its size) language unit, a communicationally autonomous macro sign which:

- has its own subject (the sender);

- has an identifiable intention which enables the recipient to interpret it;

- has a defined set of genre and stylistic features (text qualifier);

- is subject to interpretation as a whole;

- displays structural integrity and semantic cohesion;

- is subject to internal semantic division, and to logical and compositional division in the case of longer texts as well (Bartmiński, Niebrzegowska-Bartmińska 2009, p. 36 [Unless indicated otherwise, quotations in English were translated from Polish for the purposes of this article]).

The proponents of the so-called dynamic concept of text have defined it somewhat differently. Anna Duszak has indicated that "the quality of being a text stops being considered the quality of an utterance and starts being viewed as the state of mind of a person who participates in a communicative event," (Duszak 1998, p. 117). Ewa Szkudlarek-Śmiechowicz has noted that "text is a comprehensively framed sign (a macro sign) which forms during a specific social contact between language users, the structure and functions of text depend on the contextual conditions of the type of the social interaction, i.e., the type of discourse; the extent of the communicative act is defined by how comprehensive meanings are," (Szkudlarek-Śmiechowicz 2010, p. 32).

The role of texts in language education is highlighted in the Common European Framework of Reference for Languages. Its authors indicate the fact that any text transmitted through a medium becomes a communicative action, it "is central to any act of linguistic communication, the external, objective link between producer and receiver, whether they are communicating face to face or at a distance." (CEFR 2003, p. 98). In this study I shall focus on the notion of the media text, though I consider the notion of the medium differently to how CEFR does. The simplest definition of the media text is to consider it a text released in the mass media, yet for further analyses its multi-code or, as Ewa Szczęsna has proposed, multi-semiotic, polysemiotic ${ }^{3}$,

\footnotetext{
${ }^{2}$ According to Dobrzyńska, text is a "finite and organised series of linguistic elements which can jointly fulfil a communicative function, thus constituting a single global sign," (Dobrzyńska 2000, p. 287). Elsewhere she has argued: "Therefore, text is a closed system the components of which match a specific organisation. The identification of the limits of a linguistic chain is necessary for it to be considered as text" (Dobrzyńska 1991, p. 143).

3 "I understand the semiotic system (semiosphere) as a system of verbal, visual, and audio signs (monosemiotic systems), visual/verbal signs, or visual/audio/verbal signs (polysemiotic systems) together with the rules of how they should be joined. Those rules are defined by the medium which utilises semiotic systems in a manner specific for itself. That means that literature defines different rules of linking verbal signs to comics, and other rules of linking visual signs function in paintings and other in digital photography" (Szczęsna 2007, p. 17).
} 
multi-media ${ }^{4}$ and multi-sign ${ }^{5}$ nature is more important (Szczęsna 2007). I shall not analyse those individual terms in detail; they are related to text transmitted using various signs and codes, e.g., oral code + visual code; oral code + written code + visual code, etc.

Therefore, a media text is a text in the mass media; it is usually a multi-code text or, as Iwona Loewe has proposed in reference to a television text: a multimodal text (Loewe 2018) ${ }^{6}$.

When, in 2014, Urszula Żydek-Bednarczuk wrote about the utilisation of media texts in foreign language teaching, she mainly focussed on the role of the internet in the process (Żydek-Bednarczuk 2014). Grażyna Zarzycka made similar observations (2014). Today, especially after a pandemic and universal remote learning, the internet has become a common educational tool, a medium as defined by CEFR, i.e., a carrier of content. It is just as rich a source of texts as the radio, television and the press are. Further in the article, I shall indicate the role of said texts in foreign language teaching in reference to a particular thematic area: sport $^{7}$.

In media-focussed foreign language teaching, the follow teaching objectives apply:

- to use media to stimulate intellectual processes and trigger actions in the target language,

- to teach grammatical competences, listening and reading comprehension skills, and writing and speaking skills in the target language,

- to help learners become reflective users of media, and to help them analyse and use media in intercultural dialogue, and to teach sociocultural and intercultural skills. (Żydek-Bednarczuk 2014, p. 336)

All those objectives can be fulfilled using sport-themed texts, as I shall prove later in the article. Yet first I shall return to CEFR, a document which among various sample spoken texts also includes a sports commentary on football, cricket,

4 "The multimedia nature denotes the fact of the participation of various media in the creation of culture texts, the semanticisation of semiospheres, and the fact of linking and transforming them in the media of textuality" (Szczęsna 2007, p. 140).

${ }^{5}$ The development of the forms of online communication has resulted in the utilisation of writing as speech. "Written speech" as created by internet users (e.g., e-mail or instant messaging) features considerable grammatical freedom (both in terms of syntax and punctuation). However, it is not merely a record of speech, an intermediate form between oral and written forms, but it establishes a new multi-sign standard. That is evident considering, e.g., the inclusion in texts of emojis, i.e., graphic signs communicating specific emotions of their senders, or the fact of the acquisition by iconic signs of functions which have previously been fulfilled by words" (Szczęsna 2007, p. 46).

${ }^{6}$ Nowadays, a growing number of researchers argue that all texts are multimodal as they all to at least some extent utilise the verbal and visual codes or the verbal and spoken codes.

${ }^{7}$ Please note that the entire discussion regarding internet texts also applies to radio, television, and press texts. 
boxing, and horse racing events ${ }^{8}$. In following Pfeiffer's line of argumentation that the main objective of teaching a foreign language is to prepare learners to lead the most convenient life in a target community, i.e., the world of another language, one should also prepare them to be able to operate in the universe of media texts. It might seem that in a world where physical borders have no meaning anymore, media content should be available, except due to the purely linguistic barrier, for all users of the text types or genres which they might find interesting. However, as indicated by comparative studies conducted by media linguists, the difference in how media texts are constructed are extensive. As an example, I shall discuss the results of a study into the structure of the interview. The study has shown that interviews conducted in English are approx. 99\% based on past tense verbs (the present tense is used approx. $1 \%$ of the time), while in interviews conducted in German, the past tense applies to approx. $55 \%$ of verbs and the present tense to 45\% (those are arithmetic mean values of the results published for Australia and England, and Germany and Switzerland; the study only considered interviews conducted in English and German). Stefan Hauser, the author of the study, raised the issue of cultural tinting of media texts. He noted that "the concept of culture which formed based on the affinity to a nation or to a speech community was replaced by « journalistic cultures, »" (Hauser 2012, p. 151) ${ }^{9}$. He has argued that media linguists should focus on comparative studies into media texts (researching parallel texts in various languages) which could be utilised in the process of preparing the learners of foreign languages to participate in this type of culture. Similar conclusions regarding the differences in constructing utterances in the same genre apply to texts available on the internet. Using the example of live sports commentary, I have concluded that "individual commentaries differ from one another in virtually all their aspects - from text length all the way to their expressiveness ${ }^{10}$. Therefore, it seems justified to prepare recipients for receiving a genre which wo-

${ }^{8}$ CEFR lists the following examples of spoken texts: public announcements and instructions; public speeches, lectures, presentations, sermons; rituals (ceremonies, formal religious services); entertainment (drama, shows, readings, songs); sports commentaries (football, cricket, boxing, horse-racing, etc.); news broadcasts; public debates and discussion; inter-personal dialogues and conversations; telephone conversations; job interviews, and written texts: books, fiction and non-fiction, including literary journals; magazines; newspapers; instruction manuals (DIY, cookbooks, etc.); textbooks; comic strips; brochures, prospectuses; leaflets; advertising material; public signs and notices; supermarket, shop, market stall signs; packaging and labelling on goods; tickets, etc.; forms and questionnaires; dictionaries (monolingual and bilingual), thesauri; business and professional letters, faxes; personal letters; essays and exercises; memoranda, reports and papers; notes and messages, etc.; databases (news, literature, general information, etc.) - CEFR 2003, p. 95.

${ }^{9}$ At this point the issue of the discourse of the sports community arises, in which genres applicable to the needs of the community are created. Yet utterances in genres important for the community may be culturally conditioned, a fact which was indicated in the study into the interview.

${ }^{10}$ This begs a comparison with Maria Wojtak's concept of genre according to which there exist not only the canonic version, but also alternative and adaptive patterns (cf. Wojtak 2004). 
uld otherwise be familiar to them in another language version. Even the particular structure of hypertext, the lexis, and even the iconography (which is different for different languages) could be considered problematic and requiring appropriate textual competences. Most of those issues could be successfully included into Polish as a foreign language classes," (Grochala 2013b, p. 310).

I have chosen sport-themed texts from the whole universe of media texts on purpose. I consider sport an element of popular culture, as well as of national identity. I feel particular affinity to a concept of Piotr Kajak who considers popular culture within the context of foreign language teaching as a "collection of messages and everyday practices - " close at heart », requiring engagement and participation," and that is sport in a nutshell (Kajak 2020, p. 118). According to Edensor, achievements important for a nation, those which promote it globally, include the successes of major writers, filmmakers, musicians, singers, and athletes (Edensor 2004, p. 29). As Kajak aptly noted: "Imagine Polish national identity (...) without the memory of major sporting events which anyone can recall easily: without Poland vs. the USSR matches (in various disciplines) and Gerard Cieślik's 2 goals, Feliks Stamm's boxing wins, the nil-nil draw against Spain, the hockey win or Władysław Kozakiewicz's gesture (Kajak 2020, pp. 157-158). Sadly, though, sport is marginalised both in textbooks for teaching PFL (cf. Grochala 2013a) and in methodological studies.

Kajak's original sport-themed lesson concept (2016) was one attempt to fill that gap. I am expanding this area, arguing that sport texts could be easily and successfully utilised at all levels of education for teaching various language skills and for teaching all the existing subsystems. My goal is not to present specific scripts or exercises but to indicate the potential hidden in the discussed texts. As illustrations of the issues I have raised, I selected three sample media texts about sport. These are authentic texts not subjected to any alterations.

Text of a radio sport broadcast

Znamy pierwszych półfinalistów piłkarskiej Ligii Mistrzów. To paryskie PSG i londyńskie Chelsea, mimo że obie drużyny przegrały swoje mecze. Wczoraj Bawarczyków stać było tylko na jedno trafienie. Jego autorem był Éric Choupo-Moting. Swoje szanse mieli też piłkarze PSG, ale albo w bramce świetnie spisywał się Neuer, albo minimalnie mylił się Neymar, który trafił w słupek i w poprzeczkę. PSG awansowała po wygraniu w pierwszym meczu trzy do dwóch. W drugim spotkaniu Chelsey przegrała z FC Porto po efektownym trafieniu Taremiego, ale dzięki wygranej w pierwszym meczu dwa do zera dalej gra zespół z Londynu.

Siatkarskie mistrzynie Polski poznamy w sobotę. Wtedy dojdzie do decydującego starcia między Azotami Chemikiem Police a Developres Rzeszów. Wczoraj w drugim meczu półfinału po tiebreaku lepsze okazały się zawodniczki Chemika. Po przegranych dwóch setach drużyna z Polic nie miała już nic do stracenia, bo pierwszy mecz przegrała. Decydujący mecz w sobotę. (Fakty RMF, 14 Apr 2020 6:30 a.m.) 


\begin{abstract}
We have learnt the first semi-finalists of the Champions League. They are: PSG and Chelsea London despite the fact that both teams have lost their recent games. Yesterday, the Bavarians were able to score only one goal. It's scorer: Éric Choupo-Moting. PSG players also had their chances but either the excellent Neuer stood in their way or Neymar missed by a slight margin hitting the posts or the bar. PSG advanced after winning their first game three-two.

In the other game, Chelsea lost to FC Porto after a brilliant goal by Taremi but thanks to their two-nil win in the first game the London team plays on.

On Saturday we will know the Polish women's volleyball champions. It will be the deciding game Azoty Chemik Police vs. Developres Rzeszów. Yesterday, in the second game of the semi-final Chemik's players proved better in the tiebreak. After losing two sets, the team from Police had nothing to lose as they had lost the first game. The deciding game is on Saturday.
\end{abstract}

Examples of notions and activities for which this text could be used:

1. Cardinal and ordinal numbers (pierwszy, drugi, trzy, dwa).

2. The past tense (przegraty, okazaty się, spisywat się).

3. Degrees of comparison of adjectives and adverbs (lepszy).

4. Forming adjectives (siatkarski)

5. Forming participles (decydujacy)

6. Lexical antonyms (przegrać/wygrać).

7. Colloquial phraseology (decydujace starcie, nie mieć nic do stracenia, kogoś stać na coś).

8. Specialist lexis (stupek, poprzeczka)

9. Complex sentence syntax (Swoje szanse mieli też piłkarze PSG, ale albo w bramce świetnie spisywat się Neuer, albo minimalnie mylit się Neymar, który trafit $w$ stupek $i$ w poprzeczke).

10. Listening comprehension.

Text of television summaries of games

Czas zemsty nadszedł, a ta jest rozkoszą bogów, także tych piłkarskich. Ci jeszcze panujący z Bawarii chcą odwrócić zły los po przegranej w pierwszym meczu u siebie. Ci ze stolicy Francji, którzy byli już tak blisko raju w czerwcu ubiegłego roku w Lizbonie, marzą o rewanżu za tamtą porażkę na Estadio da Luz. Pierwszy krok już wykonali, ale przed nami część druga tej frapującej i pełnej dramaturgii batalii o awans do czołowej czwórki Champions League. Sześć dni temu Bayern, używając terminologii bokserskiej, był już dwa razy liczony. Ale dwa razy się podniósł, chociaż ten trzeci cios Saint Germain, drugi wyprowadzony w tym meczu przez Mbappe, znów posłał obrońców tytułu na deski. Ale nokautu nie było. Bo to jest piłka, nie pięściarski ring, a to dopiero półmetek tego starcia futbolowych gigantów.

Dobrze pokazał się Neymar, świetne podanie od di Marii i już szukanie tej przestrzeni przez Mbappe. Mbappe... Dwa znakomite prostopadłe podania, jedno 
po drugim. Świetna okazja. Z boku boiska Mbappe. Boateng. Już wbiega tam Neymar, już wbiegł tam Mbappe, który będzie schodził do lewej strony. On lubi takie wejście w drybling z bocznego sektora boiska. Próba znalezienia Neymara, co za sytuacja dla Paris Saint Germain.

- A teraz dobre czytanie gry przez Boatenga do Sane, Sane.

- Pierwsza taka akcja środkiem boiska oparta na dziewiątce i od razu taka sytuacja.

- Wychodził na dobrą pozycję Thomas Müller. Teraz znakomita sytuacja, szansa przed Bayernem, świetne uderzenie Joshuy Kimmicha.

- Skuteczność, to jest to, czego potrzebuje dzisiaj Bayern.

- Angel di Maria, Neymar, ale kiwka kapitalna.

Ale teraz jest szansa. Broni jednak Navas. Choupo-Moting i ... goooool. Choupo-Moting on trafia do bramki. Były piłkarz Saint Germain daje nadzieję Bawarczykom. (Polsat Sport 13 Apr 2021)

The time for revenge has come and that delight is reserved for gods, including football gods. The still reigning gods from Bavaria intend to reverse their bad fortune after losing the home game. The gods from France, who were so close to paradise in June last year in Lisbon, are dreaming of taking revenge for that loss at Estadio da Luz. They have already taken the first step but now's the second part of this intriguing and dramatic battle to advance to the last 4 of the Champions League. Six days ago, Bayern, to use the boxing vernacular, were given two standing counts. They got up twice, too, yet the third blow by Saint Germain, Mbappe's second in the game, sent the reigning champions back down. But it was no KO. Because this is football not boxing, and this match between the giants is only halfway through.

Neymar played a good game. An excellent pass from di Maria and immediately Mbappe was looking for space. Mbappe... Two brilliant straight passes, one after the other. Excellent opportunity. Mbappe to the side of the field. Boateng. Neymar is running in, so is Mbappe and he will move to the left. He likes to start dribbling like that from the side. He tried to find Neymar, what an opportunity for Paris Saint Germain.

- And now good reading of the play by Boateng to Sane, Sane.

- It's the first such play through the middle using the number nine and such an opportunity right away.

- Thomas Müller was moving into a good position. Now an excellent opportunity, one for Bayern, a superb shot by Joshua Kimmich.

- Effectiveness, that's what Bayern need today.

- Angel di Maria, Neymar, what a brilliant feint.

But now's the opportunity. Yet Navas saves it. Choupo-Moting and ... he scooores. Choupo-Moting scores a goal. The former Saint Germain player gives the Bavarians hope. 
Sample notions for which this text could be used:

1. Cardinal and ordinal numbers ( $d w a$, sześćć, pierwszy).

2. The past tense (podnióst się, postat, pokazat)

3. Derivative nouns (podanie, szukanie, wejście, czytanie).

4. Sports lexis (ring, nokaut, cios, kiwka).

5. Colloquial idioms and phraseology (zemsta jest rozkosza bogów, odwrócić zły los, posłać kogoś na deski, wykonać pierwszy krok, dać nadzieję).

6. Listening comprehension.

Text of online live coverage

11. min Alaba po raz kolejny przekroczył przepisy w starciu z Neymarem

12. min Lucas Hernandez uprzedził Mbappe i przerwał ofensywę gospodarzy

13. min Dagba po raz kolejny nastrzelił Choupo-Motinga i wywalczył aut dla PSG

14. min Bayern po raz kolejny próbuje ataku pozycyjnego, ale gospodarze dobrze się bronią

15. min Zbyt mocne podanie Lucasa Hernandeza padło łupem Keylora Navasa

16. min Davies ruszył lewym skrzydłem, poślizgnął się, stracił piłkę i faulował Di Marię

17. min Di Maria mocno ucierpiał w tym starciu i nie podnosi się $\mathrm{z}$ murawy

18. min Argentyńczyk potrzebował pomocy lekarzy, ale powinien wrócić do gry

19. min Kimmich zebrał piłkę przed polem karnym, jednak zbyt daleko sobie ją wypuścił i nie zdołał oddać strzału

20. min Kontratak PSG zakończył się nieporozumieniem Di Marii z Neymarem - futbolówka wylądowała w rękach Neuera (https://sport.onet.pl/pilka-nozna/ liga-mistrzow/liga-mistrzow-psg-bayern-bawarczycy-gonia-na-zywo-wynik -live/1r9zfbz)

11" Alaba once again broke the rules when tackling Neymar

12" Lucas Hernandez was quicker than Mbappe and managed to break up the home team's attack

13" Dagba once again aimed and hit Choupo-Moting and got a throw-in for PSG

14" Bayern are once again attempting a short-play attack but the home team are standing their ground

15" Lucas Hernandez passed the ball too far and it fell prey to Keylor Navas

16" Davies set off down the left wing, he slipped, lost the ball and fouled Di Maria

17" Di Maria was hurt severely in this tackle and is not getting up

18" The Argentinian needed help from the medics to return to the game

19" Kimmich collected the ball outside the penalty box but let it go too far and did not manage to take a shot

20" PSG's counterattack ended in failed communication between Di Maria and Neymar - the ball went straight into Neuer's hands 
Sample notions for which this text could be used:

1. Ordinal numbers (jedenasta, dwunasta, trzynasta).

2. The past tense (przekroczyt, uprzedzit, wywalczyt)

3. Specifying the time (szesnasta minuta, dwudziesta minuta)

4. Sports lexis (ofensywa, lewe skrzydto, atak pozycyjny).

5. Colloquial idioms (coś padto tupem kogoś).

6. Reading comprehension.

The above-presented sample notions do not exhaust the list of topics which could be discussed using media sport texts. Depending on the level of a group and its composition the teacher can adapt or purpose-develop a text, as well as use an original text as in the examples; then learners are more motivated and their satisfaction increases. In the case of homogeneous groups in terms of L1 it might be interesting to compare, e.g., online live coverage in Polish and in the learners' L1, or to introduce translation exercises at higher levels. One could also divide a group into three smaller ones, each of which could follow live coverage via a different medium (radio, television, internet), e.g., to search for colloquial idioms or ordinal numerals. Such classes add variety to a course while utilising authentic texts, which are an important element of the process of learning a foreign language.

In the summary, I would like to discuss the advantages and disadvantages of using sport texts in Polish as a foreign language classes and foreign language classes in general. I shall begin with presenting the disadvantages first. Interestingly enough, one of the first problems might be the topic itself: sport texts require the teacher to possess at least a basic knowledge of the discipline and its lexis. It would be ideal for them to have a keen interest in it or at least have a positive disposition towards it. There might also be a problem with the learners - the teacher first needs to get to know a group, discover in what its members are interested, etc. ${ }^{11}$ It may be the case that none of them are sports fans and then to introduce such media texts would be pointless ${ }^{12}$. There is one more limitation: if a group is culturally diverse its members may be interested in different sports (e.g., polo, cricket or sumo wrestling - there are few media texts in Polish about these sports). There is also the problem of the mistakes which appear in live coverage, though this element could be considered a positive feature as it would enable learners to become familiar with the Polish of the media ${ }^{13}$.

${ }^{11}$ During the winter semester of 2020 at an online course at the B1 level in a group that was extremely diverse in terms of ethnicity, age and occupation, I spent a long time trying to find a common thread between the learners who had never met in person and only knew each other by their names and voices... A month into the course I managed to find two: food and sport. Apparently, some of them supported the same teams, they were avid fans of the same sports, and there were even fans of sports which are niche in the European context, i.e., sumo wrestling, who described to their fellow learners the beauty of the sport.

${ }^{12}$ That is a problem when only some of the learners are interested in sport.

${ }^{13}$ Another disadvantage could be the contrast between specialist lexis and the rich array of metaphors and idioms and the notions appropriate at lower levels (e.g., ordinal numerals or the past tense). 
Nonetheless, advantages outweigh disadvantages considerably. First and foremost, learners come into contact with very recent texts which can be replaced on a regular basis so that they do not lose their appeal. This type of text carries a high linguistic potential, and, in the case of television coverage, texts are accompanied by images, which facilitates understanding. The teacher has relatively easy access to material, in particular to online live coverage. The content is international in nature even if it includes culture-specific elements, especially those related to journalistic culture and the knowledge of the target reality. It also possesses an integrating quality, which can result in increased motivation to learn the target language.

Finally, allow me to return to the various approaches linguists have to text and to media text in foreign language teaching in particular. Those mainly indicate the fact that a text is a state of mind which constitutes a link between its author and the recipients; it stimulates intellectual processes and triggers actions in a foreign language. Once familiar with original texts, learners can live comfortably in the target linguistic setting; they not only expand the learners' knowledge of the target language but also the related culture. I believe that all those qualities are characteristic of media sport texts and that is why it is worth introducing them into the education process. As Kajak has argued: "You cannot avoid culture texts and content in the process of foreign language teaching. The only limitation (...) are the needs of the learners" (Kajak 2020, p. 116).

\section{REFERENCES}

“Acta Universitatis Lodziensis. Kształcenie Polonistyczne Cudzoziemców”, 2008, vol. 16.

“Acta Universitatis Lodziensis. Kształcenie Polonistyczne Cudzoziemców”, 2010, vol. 17.

“Acta Universitatis Lodziensis. Kształcenie Polonistyczne Cudzoziemców”, 2011, vol. 18.

Bartmiński J., Niebrzegowska-Bartmińska S., 2009, Tekstologia, Warszawa.

Dobrzyńska T., 1991, Tekst: próba syntezy, "Pamiętnik Literacki”, col. 2, pp. 142-183.

Dobrzyńska T., 2000, Tekst, in: J. Bartmiński (ed.), Wspótczesny język polski, Lublin, pp. 293-314.

Duszak A., 1998, Tekst, dyskurs, komunikacja międzykulturowa, Warszawa.

Edensor T., 2004, Tożsamość narodowa, kultura popularna i życie społeczne, Kraków.

Europejski system opisu kształcenia językowego (ESOKJ), 2003, Warszawa.

Grochala B., 2013a, Czy podręczniki do nauczania jpjo przygotowuja do uczestnictwa $w$ wydarzeniach sportowych?, in: J. Mazur, A. Małyska, K. Sobstyl (eds), Glottodydaktyka polonistyczna w obliczu dynamiki zmian językowo-kulturowych i potrzeb społecznych, vol. 2 , Lublin, pp. 57-66.

Grochala B., 2013b, Kompetencja komunikacyjna a gatunek - o relacji internetowej na żywo, "Acta Universitatis Lodziensis. Kształcenie Polonistyczne Cudzoziemców”, vol. 20, pp. 303-311.

Hauser S., 2012, Teksty medialne w ujęciu kontrastywnym i kulturowym. Rozważania metodologiczne i przyktadowa analiza, "Tekst i Dyskurs - Text und Diskurs", no. 5, pp. 127-154.

Kajak P., 2016, Lekcja 25 „,Mistrzem Polski jest Legia, Legia najlepsza jest”, in: A. Rabczuk (ed.), E-book do nauki języka polskiego jako obcego wraz z ćwiczeniami interaktywnymi dla poziomи A, Warszawa. 
Kajak P., 2020, Kultura popularna w nauczaniu polszczyzny jako języka obcego. Wstęp do kulturoznawstwa glottodydaktycznego, Warszawa.

Loewe I., 2018, Dyskurs telewizyjny w świetle lingwistyki mediów, Katowice.

Szczęsna E., 2007, Poetyka mediów (polisemiczność, digitalizacja, reklama), Warszawa.

Szkudlarek-Śmiechowicz E., 2010, Tekst $w$ radiowej i telewizyjnej debacie politycznej. Struktura - spójność - funkcjonalność, Łódź.

Wojtak M., 2004, Gatunki prasowe, Lublin.

Zarzycka G., 2014, Media w nauczaniu języków obcych. Koncepcje teoretyczne i wybrane rozwiąania metodyczne, "Acta Universitatis Lodziensis. Kształcenie Polonistyczne Cudzoziemców", vol. 21, pp. 321-333.

Żydek-Bednarczuk U., 2014, Tekst medialny w edukacji glottodydaktycznej, “Acta Universitatis Lodziensis. Kształcenie Polonistyczne Cudzoziemców”, vol. 21, pp. 335-344.

\section{Beata Grochala}

\section{TEKSTY SPORTOWE W NAUCZANIU JĘZYKA POLSKIEGO JAKO OBCEGO}

Słowa kluczowe: tekst, tekst medialny, medialne teksty sportowe, kultura popularna w nauczaniu języka polskiego jako obcego

Streszczenie. W artykule zaprezentowano potencjał medialnych tekstów sportowych w zakresie ich wykorzystania na zajęciach z języka polskiego jako obcego. Autor zaprezentował różne definicje tekstu, aby wykazać, że może być to nie tylko pojęcie językoznawcze, ale również pewien element wspólnotowy, stan ducha. Następnie wskazano na rolę tekstów medialnych w glottodydaktyce. W kolejnej części autor odniósł się do roli kultury, zwłaszcza kultury popularnej w nauczaniu języków obcych. Odwołano się także do badań pokazujących różnice w sposobie konstruowania tych samych gatunków medialnych w zależności od obszaru językowego. Autorska propozycja dotyczy tekstów sportowych: radiowych, telewizyjnych i internetowych. Wskazano ich potencjał glottodydaktyczny, pokazano konkretne obszary, w jakich mogą mieć zastosowanie. W konkluzji autor zaprezentował wady i zalety wykorzystania medialnych tekstów o tematyce sportowej na zajęciach z języka polskiego jako obcego. 